\title{
The Potential and Social Acceptability of Renewable Energy sources in North Iraq: Kurdistan Region
}

\author{
Diler Haji Morad \\ Department of Architecture engineering, Duhok University, Kurdistan Region - Iraq
}

\section{ABSTRACT}

Kurdistan region government(KRG) is located to the north of Iraq, its Energy System has suffered from a lack of electricity, and many challenges to be overcome to meet future increases in demand for power, about $85 \%$ of the production of power is almost depended on fossils fuels, while the remaining $15 \%$ is covered by hydro-electrical plants. Therefore, the renewable energy sources are alternative sources of energy for reducing energy demand and $\mathrm{CO} 2$ emissions in KRG. In order to review the Kurdistan potential renewable energy and social-acceptance toward renewable energy source use and implementations, mixed methodology was used qualitative and quantitative to provide the most complete analysis of study problems. In this study, the potential renewable energy sources (RES) has been examined as well as the survey which was designed with three groups of questions: awareness of renewable energy sources, person background information and willingness to invest in renewable energy sources. The result showed that Kurdistan region has a great ability to utilize renewable energy sources and long-term economic viability of using RES in house wasn't clear for $40 \%$ of 320 interviews. About $63 \%$ of the participants were ready to pay extra cost to get renewable energy. The majority of the participant think that public sector should take the first step towards renewable energy production as well as providing incentives and business models to motivate peoples to implement RES in their building.

KEYWORDS : Social acceptance; Kurdistan region government (KRG), Renewable Energy sources (RES).

\section{INTRODUCTION}

Since 1991, renewable energy has become significant issue for many countries and governments in the world because of increasing global apprehensions about shortage of fossil fuels and climate changes (Lund,2010). Concerns about climate change and energy security are enforcing important changes in how electricity and energy are specifically. Currently, Kurdistan for its energy supply meanly dependents on fossil fuels, with about $85 \%$ of its energy produced by Gasoline and natural Gas. while the remaining $15 \%$ are covered by hydro-electrical plants and by using Solar energy which

Academic Journal of Nawroz University

(AJNU) Volume 7, No 4 (2018).

Regular research paper : Published 21 December 2018

Corresponding author's e-mail : diler.morad@uod.ac

Copyright (C2017 Diler Haji Morad.

This is an open access article distributed under the Creative

Commons Attribution License. is very limit less than $1 \%$ Fig.1. it has fossil fuels sources but due to the lack of electric generator electricity demands cannot be satisfied especially in winter and summer because the loads become at the pick-level. Therefore, the region needs to buy electricity energy from Turkey and Iran (Mirza et al., 2015). Renewable energies as native energy sources will have a significant role to decline the level of energy produced by fossil fuels. Unfortunately, government is still unable to adopt an energy policy, including modern energy technologies and exploit the maximum of renewable energy sources. The study aim is to analyses the potential level and aware-ness of renewable energy sources in the Kurdistan region and Society. Moreover, this research also noted how the acceptance and thinking rate about renewable energy sources were differ specifically for the respondent's own use in their houses or neighboring environment. Furthermore, the results of study provide a treasure-trove of knowledge in various methods. For instance, they provide us the potential of renewable energy sources in Kurdistan, in 
addition, they provide us a significant path to learn how and what kind of stages have already been taken to make awareness about the renewable energy sources and climate change so far in Kurdistan, as well as they serve us to examines the community attitudes towards renewable energy Application in detail, also to obtain information about what different types of renewable technologies and sources they are aware of.

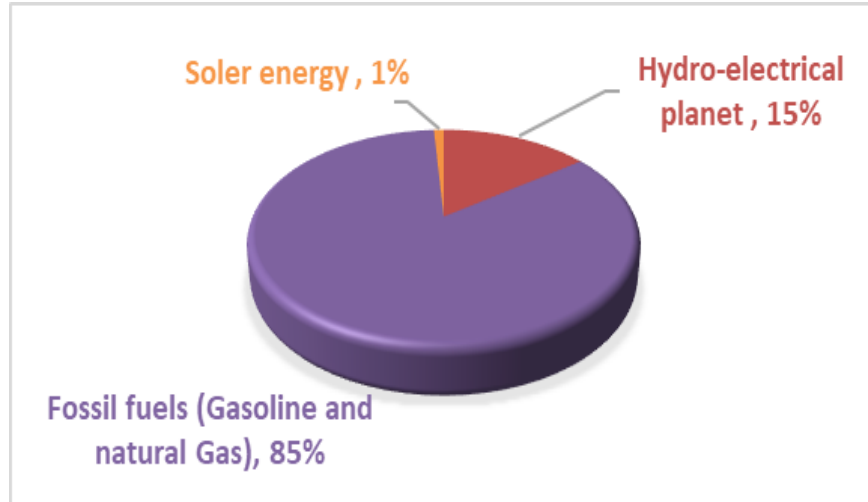

Fig (1) : Kurdistan Energy Sources for energy supply (Mirza et al., 2015)

\section{BACKGROUND}

This article claims that the Kurdistan region is non-or slowly progressing towards the implementation of several methods to save power by using renewable energy sources. Consequently, a work to make community awareness isn't only significant but even essential in this regard. The renewable energy sources for energy production are varied, wind turbines (different scale); solar photovoltaic panels, on offshore location and designs; energy from water; hydro power such as wave devices and tidal, energy from waste plants; such as biomass fueled plant. Meanwhile each source captures different natural sources in different methods, the social, economic impacts and environmental, of each source differ. Therefore, potential of renewable energy source and the need of measuring social-acceptability of renewable energy sources is important for understanding a public's social viewpoints in terms of climate change issues and using renewable energy sources (Devine-Wright, 2007). Many articles and researches noted that there are some indicators that can be used to measure social acceptance in a specific context (Devine-Wright, 2011; Viswanath and Hillol, 2008; Hall et al., 2013). Between these are the age group, participants, political beliefs, socioeconomic back-ground, behavior and attitudes. Moreover, the perceived usefulness, facilitating conditions, intention to use, trust, cost, position and participant's place in relation to the renewable energy all work a vital role. This research has used these variables to examination how Kurdistan people aware about the renewable energy technology, source and climate change cases.
Other community acceptance measurable variables such as, time, perceived adaptability, perceived sociability, anxiety, perceived enjoyment, culture, social impact, system's reliability and perceive issues of use are left for a future research. Furthermore, despite researches on people attitudes to-wards renewable energy sources, real understanding of the dynamics of social-acceptance remains difficult to find. Devine-Wright (2007) argued that one of the reasons for this is the determinants of social-acceptance are rarely measured as a whole, taking account of the psychological, contextual and multiple personal factors involved. A range of potential explanations can be known in the literature for difference levels of social-acceptance of various renewable energy sources and technologies (Jeffrey and Michael, 2010; Devine-Wright, 201; Wolsink, 2000). Devine Wright (2007) has noted a variety of possible explanations can be known at three levels of investigation: first level includes individual information such as gender, age, income, class. Second level includes social-psychological such as direct and knowledge experience, place attachment, perceived influences, political and environmental beliefs, and last on is contextual. For example, in the United Kingdom, some local investigations and surveys have found both higher levels of opposition and awareness to-wards renewable energy sources between older respondents. On the other hand, some national researches there found levels of opposition and awareness to be in older and younger group (age 15 - 23 and 66+) in comparison with middle aged interviewers (age $34-45$ and 54 - 65). The researches results showed that support levels for renewable energy appear to correlate with age, the young-age people less supportive than' older-age (Somerset County Council, 2004) (Jan and Milan, 2012; Populus, 2005). In addition, in the Kurdistan some studies found on potential of wind and solar energy, both resulted that Kurdistan have a good opportunity to obtain solar and wind energy heat power (Azabany and Khan, 2014; Husseinet al., 2012; Scddeek and Wahab, 2013; Hamadamin, et al., 2015). In contrast, no studies have been investigated on social-acceptance in Kurdistan. This study will be unique as it's a mix of both potential and social-acceptance of renewable energy sources.

\section{METHODOLOGY}

This study uses mixed methods, qualitative and quantitative methods. The main reason to use mixed techniques (qualitative and quantitative) in doing their study to provides the most complete analysis of study problems. The qualitative methodology has been used for investigate potential of renewable energy sources, the data was collected from various sources including books, websites and journals about the Kurdistan energy system and potential of renewable 
energy sources and technologies (hydro power, wind energy, biomass, solar energy). The quantitative methodology (survey questionnaire) has been used for measure and investigate the community knowledge level of social acceptance of renewable energy sources. This methodology has helped to include persons from various backgrounds to improve the sample area in order to make the results of study more objective, reliable and substantial (Christian and Thomas, 2017). To ensure a valid survey, the people's understanding and eliminated our professional-bias should be taken in to account in the questions, it was conducted face to face because we wouldn't know what educational background they are from, before they provide their background information during interviews. However, for this research, our questionnaire contained of 12 multiple-choice questions, which covered several subjects that can be realized from the next sections, for instance, an open-ended questionnaire list for the interviewer has been prepared to contain two sections. Section one of the questionnaire list about participants' background variables information such as participants' job situation, age, etc. Section two was concerned with the people awareness and willingness to invest in renewable energy sources. This involved related information like: perceptions, usefulness, facilitating conditions, attitudes, participant's position, culture, intention to use, cost about the RES, etc. Moreover, most questions were set to be closed but not open ended. The aim was to define and isolate categories precisely before research process. A total number of people responded and participants for the study about 320 people, the respondents involved for the study come from randomly different age-groups, and they divided in to three groups of ages between15-24, 25-45 and 45-65). These groups of age were selected specifically to know the age condition role on socialacceptability of RES. The profession of participates were employed, unemployed and students. This survey was conducted in Duhok, Erbil and Sulaimani cities. In this study, three questions in the section one was addressed to understand the back-ground information of all the participants counting locations, occupations and age group of the interviewees shown in (Figs.10-12). while section two, eleven questions were asked to understand how social-acceptable for the renewable energy sources in Kurdistan region are. The nine questions are classified in to (two parts) from one to four (Table 3) and from five to nine (Table 4) to measure the participants' awareness of RES and the participants' willingness to invest in RES, respectively. In this research, the scope of the sample interviewee was small but varied. Such a sample can't represent the attitudes and voices of all the Kurdish society about socialacceptability of renewable energy sources. While, this survey can be measured as a good beginning point for extended future surveys.

\section{KURDISTAN ENERGY SYSTEM}

Before 1991, the electricity of Kurdistan was provided by Iraqi central government. But after 1991, when the region became an independence government the electricity supply system in Sulaimania, Dohuk and Erbil has suffered from a severe damage for example many power stations and substations were ruined by explosives or destroyed. In 1994, it had been cut off from the national grid, power supply of Sulaimani and Erbil governorates were depended on hydropower stations of Derbandikhan and Dokan while Dohuk had no source for power supply for one year. During 1998, the electricity power generation, transmission, distribution and substations systems became very weak, and electricity power supply was limited to $3-5$ hours daily, in some areas reduced to one hour daily or no supply (UNDP, 2015). In 2013, the Kurdistan Region electricity sector has significantly improved due to incredible development in economy. The electricity power supply increased more than 20 hours per day. While, in the last three years, it has shown an increasing of population locally about $2.61 \%$ yearly and high number of refugees about 1.8 million from neighbors (Iraq and Syria) (Ekurd, 2016). This situation makes an excessive influence on increasing the amount of energy consumption and demand. In 2016, the electricity market share shown, the domestic (household) sector is the largest 54\% while the Agriculture sector represents $13 \%$ of the consumption, and the government and commercial have the similar consumption accounts $12 \%$, while industrial sector is the lowest by $9 \%$ Fig. 2 (Issa, 2014). The main consumer of electricity is domestic sector due to the increased use of electricity power for air-conditioning, water heating, space heating and cooking especially in winter and summer seasons. Today, the total capacity of installed stations over the Kurdistan region is about 3200MW Fig.3 (Yassen, 2016). Figure 4 shows that the average distribution of electricity power has increased from 339MW to around 2800MW and the maximum demand rises from 925 to 5500MW since 2004 (Issa, 2014). That means it needs nearly $2700 \mathrm{MW}$ to satisfy demand of electricity power for 24 hours daily. The total demand of electricity is increased in the last twelve years (2004-2016) by 15\% annually. The region has been affected by the significant increase in the number of refugees over the past three years, as well as tourists during the summer months and economic crisis (kurdishglobe, 2013).

\section{WHY RENEWABLE ENERGY SOURCES}

Kurdistan electricity power demand is rising Significantly, it makes a big impact on the environment (increasing of $\mathrm{CO} 2$ emission) as a result of the burning of a large amount of fossil fuels (Hamed et al.,2013). 
The Meteorological Department of Kurdistan has collected statistics, which emphasizes the global changes in weather-patterns locally. Since 1990, the temperature has been risen about (1 C) (Fig. 5), and rainfall has been decreased in the whole of region (Qusai and Lookman, 2012). Therefore, it is important to emphasize that a significant increase in the share of renewable energy sources in the electricity generation sector and will play a key role in achieving the $\mathrm{CO} 2$ reduction targets.

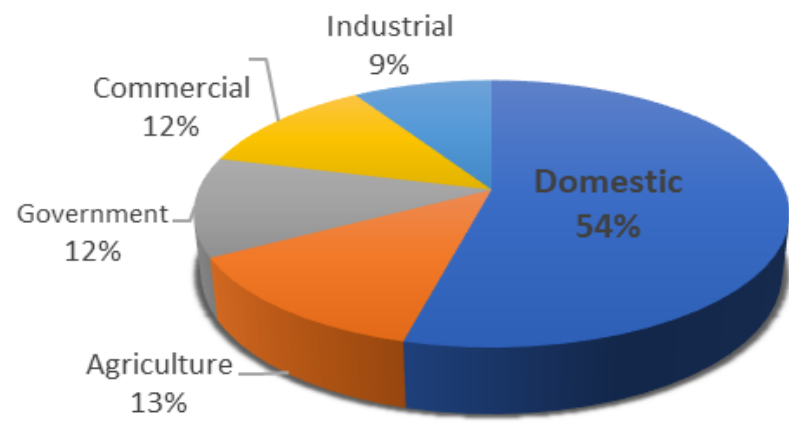

Fig (2) : Electricity demand by sector (Issa, 2014)

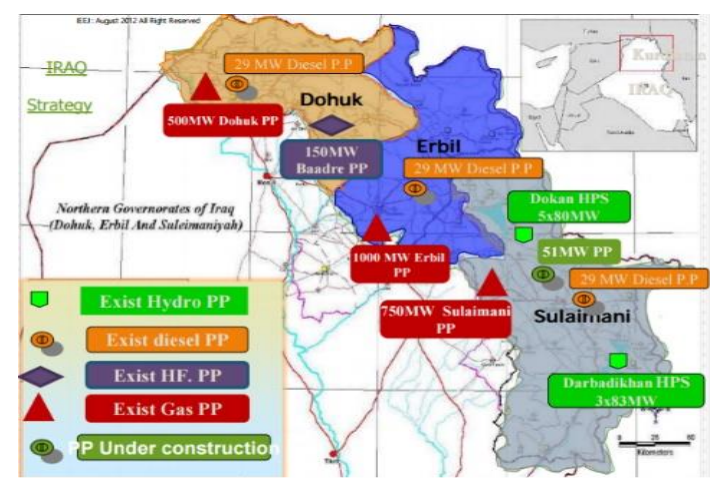

Fig (3) : Existing and Under Construction Electricity Power Station in KRG (Yassen, 2016)

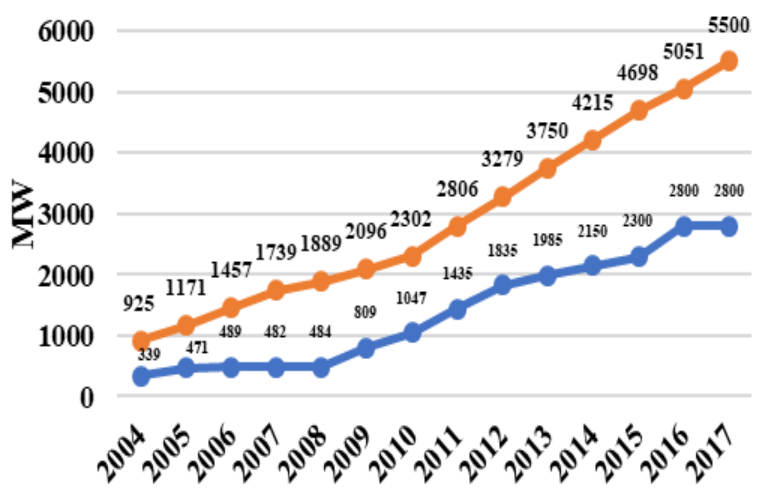

$\longrightarrow$ Aver age Distributed load $\longrightarrow$ Max. Demand of pow er Electricity

Fig (4) : Average Distribution and Max.

Demand of Electricity Power in KRG (Yassen, 2016)
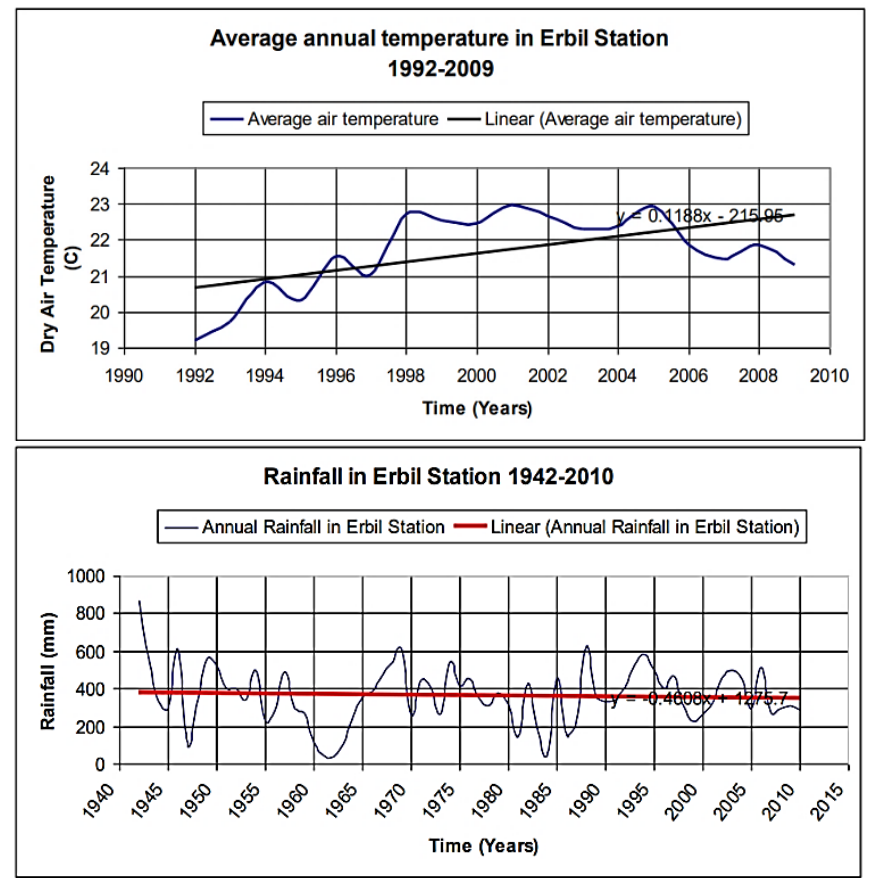

Fig (5) : Average Annual Temperature and Rainfall in Erbil (Qusai and Look man, 2012)

\section{KURDISTAN REGION RENEWABLE ENERGY SOURCES.}

\subsection{Hydro Power}

Kurdistan geographically is very rich in forest, mountain, river, streams and lack. There are two main sources of water. The first one is Rainfall and Snow, the annual average precipitation around 325 up to $800 \mathrm{~mm}$ (Fig.6) (Qusai and Lookman, 2012). usually the precipitation starts in September and ends in May. Second one is Surface Water (Rivers, Streams), the annual amount of water flow from the main rivers (Sirwan Lesser Zab Greater Zab, Awa sip and Khabur) about 30 Billion cubic meters, but around $60 \%$ is inside region, which mean nearly $(18 \mathrm{bcm})$ table 1 (Malik, 2014). The result of collecting data from the annual average Rainfall, Snow and water flow from rivers in the region, it could be put on a reasonable judgment on the availability of hydroelectric power. Nowdays, Kurdistan region uses only hydropower as renewable energy source to generate electricity power. but it is very limited in two station Dokan (400 MW) and Darbandikhan (250MW) on the Sirwan and Lower Zab rivers, with maximum power generation (600 MW). The hydropower sector has not been used in the good way but still has a good opportunity to develop and support energy generation sector table (2). The table shows the government plan to develop hydroelectric sector by building many dams and stations in the different areas in KRG (Yassen, 2016). 


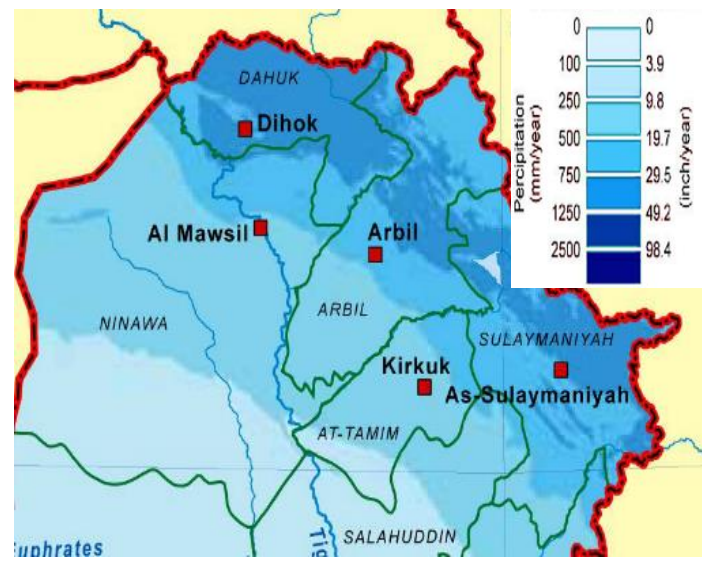

Fig (6) : Average Annual Precipitin in Kurdistan region

Table (1) : Main River in KRG (Malik, 2014)

\begin{tabular}{|c|c|c|c|}
\hline Rivers & Length & $\begin{array}{c}\text { Annual } \\
\text { flow m3 }\end{array}$ & $\begin{array}{c}\text { Inside } \\
\text { Kurdistan }\end{array}$ \\
\hline Lesser Zab & 400 & 7.07 & 64 \\
\hline Greater Zab & 392 & 14.3 & 58 \\
\hline khabour & 160 & 2.2 & 42 \\
\hline Awa Spi & 230 & 0.7 & 100 \\
\hline $\begin{array}{c}\text { Sirwan } \\
\text { Total Amount } \\
\text { Water }\end{array}$ & 384 & 5.86 & 41 \\
\hline
\end{tabular}

Table (2) : large dam and hydropower projects feasibility study \& re-evaluation (Yassen, 2016)

\begin{tabular}{|c|c|c|}
\hline project name & $\begin{array}{c}\text { installed } \\
\text { revised } \\
\text { capacity MW }\end{array}$ & $\begin{array}{c}\text { Proposed } \\
\text { construction } \\
\text { time years }\end{array}$ \\
\hline Bekma dam & $1500-650$ & 8 \\
\hline Taq-taq dam & $400-270$ & 6 \\
\hline Bakerman dam & 52.5 & 5 \\
\hline Mandawa dam & 764 & 6 \\
\hline 21 Small dams & 900 & 7 \\
\hline
\end{tabular}

\subsection{Solar Energy}

Kurdistan located between $\left(42^{\circ} \mathrm{E}\right)$ and $\left(46^{\circ} \mathrm{E}\right)$ longitudes and $\left(34^{\circ} \mathrm{N}\right)$ and $\left(37^{\circ} \mathrm{N}\right)$ latitudes, all parts of region enjoy with a lot of sunny days with large differences in temperature between summer and winter and between day and night. summer period (June, July and August) are the hottest months, the highest temperature is about $42 \mathrm{C}$ and hottest day up to $48 \mathrm{C}$, as well as the average of bright sunshine per-day is about $12.5 \mathrm{~h}$, whilst the average temperature is reduced in winter (December and January) which are the coldest months to $2 \mathrm{C}$ and coldest day drops to $-5 \mathrm{C}$, while the average of bright sunshine per-day decline to $5.5 \mathrm{~h}$. Daily solar radiation differs from about $7.7 \mathrm{kWh} / \mathrm{m} 2$ in the hottest period of the year, (June, July and August), to about $2.4 \mathrm{kWh} / \mathrm{m} 2$ in coldest period (December and January) Fig.7A,B (Hamadamin et al., 2015).

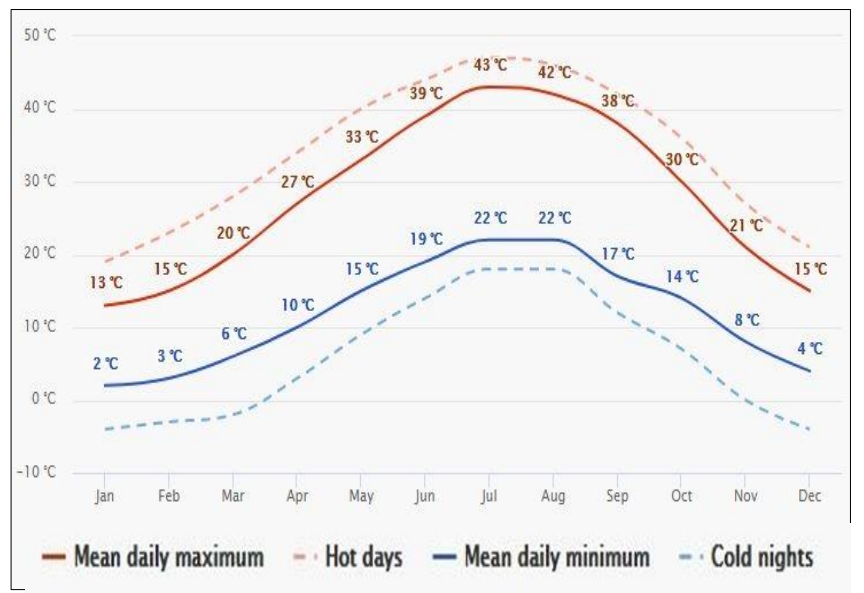

Fig (7A) : Average Annual temperature in Kurdistan region, (www.meteoblue.com)

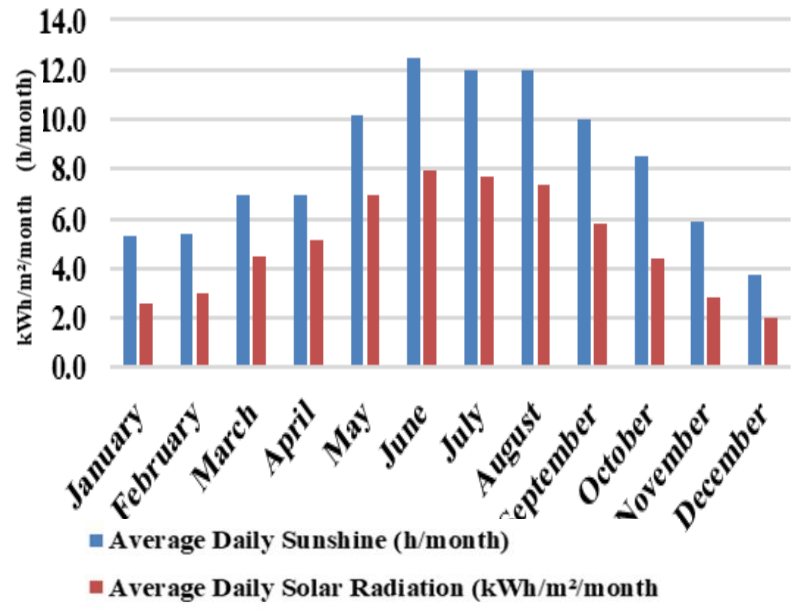

Fig (7B) : Average Daily Sunshine and Daily Solar Radiation. (Hussein and Miqdam, 2012).

The Average yearly solar radiations in different areas in region are very close to each other around 4.9 $\mathrm{kWh} / \mathrm{m} 2 /$ day that means Kurdistan have abundant and well distributed Soler energy. According to the researcher's, statistic on the efficiency of PV systems in the region shows that it can depend on the Solar energy 
as mean renewable energy source with capacity factor around 70\% which mean satisfactory (Mirza, 2015). Another study makes comparison between KRG with UK on the $20 \%$ efficient Silicon solar cells. They found out, using silicon solar cells for 307 days, that Kurdistan could generate $14.4 \mathrm{kwh} /$ day of electricity. While the UK can generate $4.8 \mathrm{kwh} /$ day, which means that Kurdistan is three times more efficient and more active in generating electricity than the UK. In the both researches it's shown the region has great opportunity to use Solar energy for generating electricity power (Azabany and Khan, 2014). There are many systems and technologies of solar energy that can be applied, Photovoltaic (PV) systems is suitable for producing electricity in city center and village. Solar thermal systems (Solar water heating) especially in winter, Concentrated solar power (CSP) especially in summer from the long day's sun-shine. Implementations of this system and its efficiency depend on many factors, orientation (latitude and longitude), environmental (temperature, solar intensity, wind, rain, humidity, dust, pollution, etc.) (Hussein and Miqdam, 2012).

\subsection{Wind Energy}

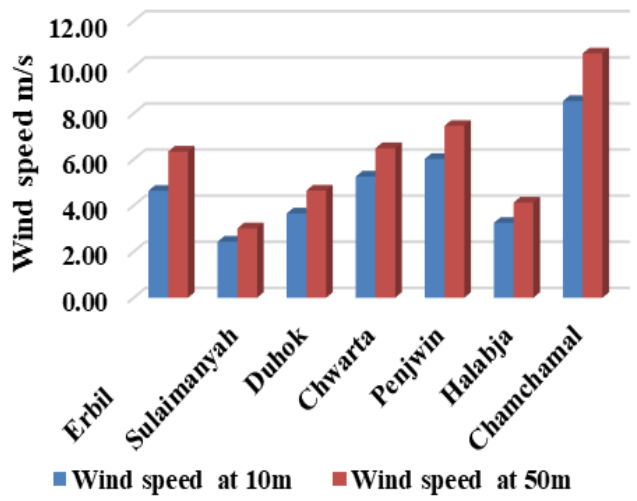

Fig (8) : Average wind speeds at $\mathrm{m} / \mathrm{s}$ at $10 \mathrm{~m}$ and 50m height (Scddeek and Wahab, 2013). Wind energy resources widely used as renewables sources that reducing green gas influence and has potential to provide reliable, clean and an energy output to decreasing electricity consumption (Scddeek and
Wahab, 2013). generally, the region in summer is exposed to located under the impact of sub-tropical high-pressure belts and Mediterranean-anticyclones. winds direction is mostly west, south west to north. in winter affected by Mediterranean-cyclones moving east to north-east over the Kurdistan area. Wind power generally moderate or light strength, they hardly reach gale force. Over the region, winds are quite variable in direction due to orography and local-heating impact grate rule in the determination of local-wind strength and direction (Ahmed and Mohammed, 2010). According to the statistic from 7 stations around Iraq Kurdistan region at $10 \mathrm{~m}, 50 \mathrm{~m}$ Hight found potential of high wind is not typical in Kurdistan. Some parts are recognized as having annual mean wind speeds more than $5 \mathrm{~m} / \mathrm{s}$ at $10 \mathrm{~m}$ and $50 \mathrm{~m}$ height like Chamchmal Fig.8. These areas are located in the south-west zone of the region. These locations may be very hopeful for wind-turbines installation to generate electricity power. By the way at many parts in the region has average wind speed around 3-5 m/s. Recently, the haven't made any plan to develop this system in the region (Scddeek and Wahab, 2013).

\subsection{Biomass}

Biomass is a widespread resource includes residues from forestry, animal, agricultural, industrial and sewage sludge, and municipal solid waste (residues produced by the public service, commercial residential sectors and burned in special installations for the production of power and heat (Hussein and Miqdam, 2012). The forest covers around $36 \%$ of region, about 1.5 million hectares Fig.9. A large part of the forest includes mountains. The most area of Kurdistan region is arable land, most of the cultivated land is rain-fed, which are located in different microclimatic zone. In addition, there are thousands of villages distributed over the mountain inhabited by farmers and they have cattle and sheep (Mohamed, 2011). According to the above data, it can be estimated that the region is very rich in biomass source, but unfortunately, this sector is neglected by government. the government should make investigation on biomass source as alternative energy. 

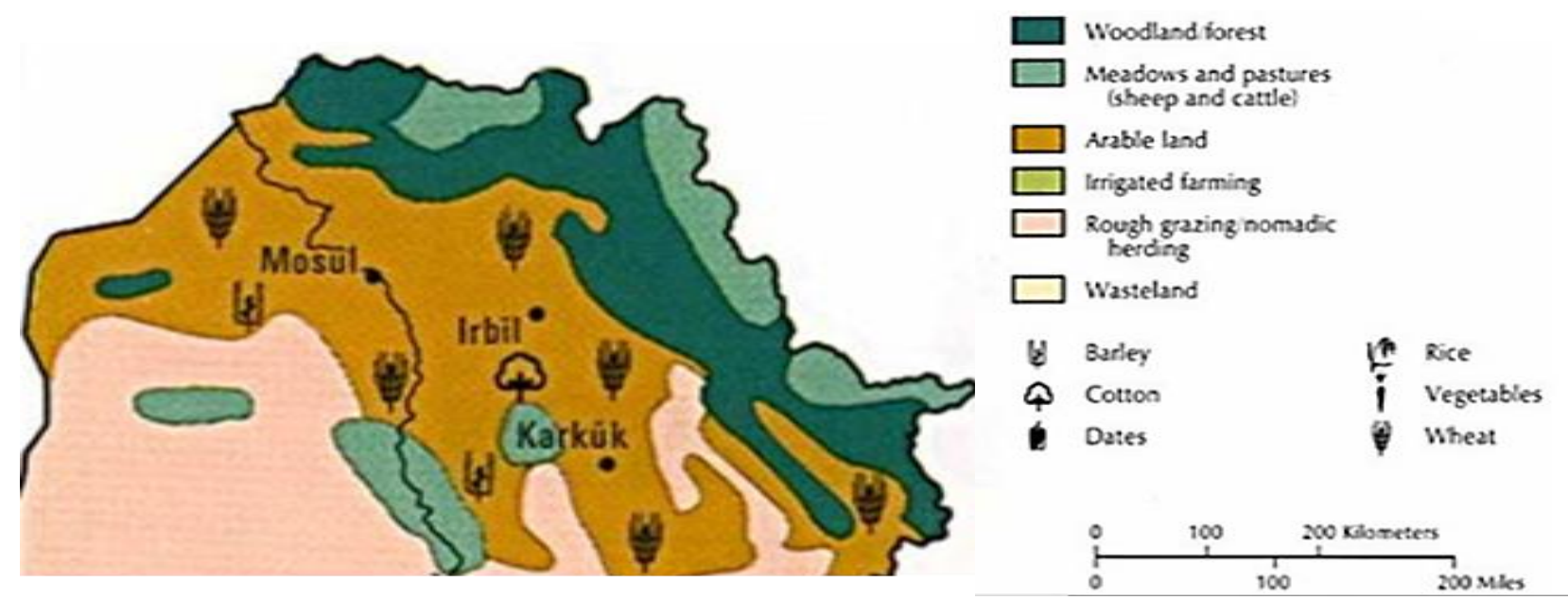

Fig (9) : The Land Use for The Major Crops in KRG (Mohamed, 2011)

\section{RESULTS \& DISCUSSION}

\subsection{Interviewees Background information}

in the survey, a total number of 340 respondents participated, unfortunately, 20 questionnaire surveys were rejected due to incomplete the answers. the participants from different age level in order to have an idea of the effect of age on the results. The majority of the participants were aged between 25-45 years old about $45 \%$, whereas the other age group between $15-25$ and $45-65$ years old about $35 \%$ and $20 \%$ respectively (Fig.10). The largest group of participants were employed around $60 \%$, While the rest group of participants were students and unemployed about $25 \%$ and $15 \%$ respectively (Fig. 11). In respondent's current state in terms of students, unemployed and employed, there seems to be a positive correlation between income and levels of support for different renewable energy source technologies. in this study, we found that the younger people more supportive for renewable energy technology to-wards better environment than others. Figure twelve shows that Erbil have made more interviews than Duhok and Sulaimani due to higher share of renewable energy technology. this might explain some of the differences in social-acceptance of renewable energy source technology and experiences.

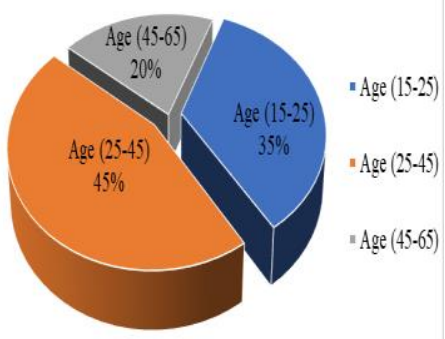

Fig (10) : Section one: background information

(interviewees age groups)

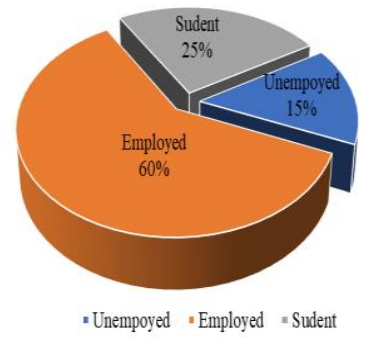

Fig (11) : Section one: background information (interviewees Profession)

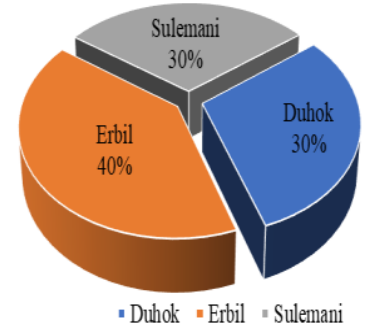

Fig (12) : Section one: background information (interviewees Location).

\subsection{Interviewees awareness of renewable energy source}

The question one deals with the very public question about the aware-ness concerning climate change as a worldwide issue. This question was set deliberately to help participants by presenting the need and concept of using renewable energy to-wards healthier environment. Nearly $71 \%$ as majority of participants need to save environmental resources, while approximately $29 \%$ of participants believe that it doesn't affect them-personally. Anyway, the answer 'I don't care' weren't received. This proposes that community are in general aware about climate change and do want to avoid it. It must be addressed that the other $29 \%$ of participant are the oldest age group who fundamentally believes that they alone can't contribute to help prevent global warming. The question two tested the participants information or awareness about the varied types of renewable energy sources technology that they are known. As it can be renowned 
the question it-self provided them with various choices, specifically biomass, wind power, hydropower and, geothermal and solar power. Nearly $93 \%$ of participates were known as a minimum about one choices of renewable energy sources, but unfortunately $7 \%$ of respondent were unfamiliar with any types renewable energy sources and technologies, most of them were oldest age and unemployed. The question three was tested and more focused on the participants answers based on who must take the first step to-wards production of renewable energy. Approximately $70 \%$ of participants proposed that it must be the responsibility of the public sector. While there were different suggestions as $20 \%$ of participants propose it as responsibility of the energy-distributors, whereas about $10 \%$ propose energy producer. So maybe this must be started by the public-sector, but the energy suppliers and producers must be involved in the serial operation of green energy production. This question is hard to answer, as this is more than a political decision including high-level lobbing of energy suppliers, investors and energy producers. However, the public and other opinion isn't sufficient to excuse the role of involved sectors in the power generation chain. Therefore, the revolution has to start from the top-tier. The fourth question was more-focused on the importance of green-energy and its local production. Approximately $60 \%$ of participants see this as veryimportant, while nearly $40 \%$ of the participates it had average importance and the answer 'Doesn't matter' weren't received. This conflict may be a result of awareness and lack of awareness of renewable energy in Kurdistan. it is difficult to know the reasons $40 \%$ of participates have answer it as average, this may be due to other factors and unawareness.

Table (3) : Section two: The survey results questions 1-4 (interviewees awareness of RES).

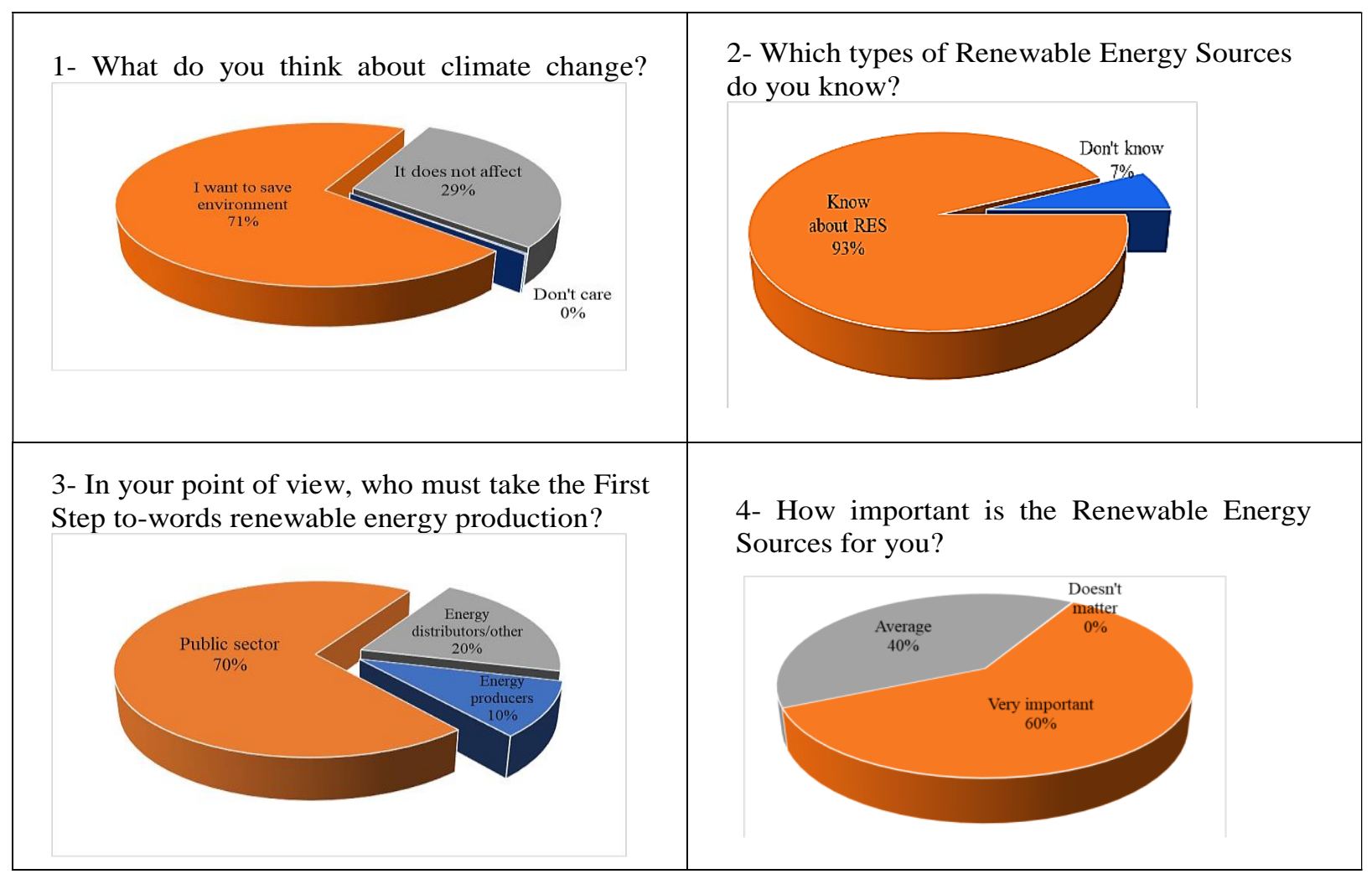

\subsection{Interviewees willingness to invest in RES.}

The question five was formed to know what participates think about having solar panels and small wind turbines as part of their roof. The majority of responses are (May be by $60 \%$ ), whereas about $30 \%$ of respondents are (yes). While, nearly $10 \%$ of respondents have rejected to have small wind turbines and solar panels on their roofs. Thus, it can be understanding that people are actually not sure about accepting-them as part of everyday scenery. This image shows how perceptions of equality and levels of confidence influence social-acceptance of renewable energy developments. In order to raise the level of surety between people, governmental authorities must introduce and highlight or construct at minimum one passive house building in each city. This practice will announce and help grow sureness between community to accept renewable energy simply. May be the cost factor are the reason some people unsure of having renewable energy sources in their roof. Therefore, the 
question six was formed to know that the current RES is expensive. The results were surprising, as $65 \%$ of participants don't had any idea about the cost of renewable energy whereas, $25 \%$ of participants believe it is expensive. While $10 \%$ suggested otherwise. Based on these responses, the public-sector or Government should offer clearer model data to peoples. These business models should be guided by inhabitant's guidance on long term savings, the high initial costs, benefit and life cycle of renewable energy sources. The seventh question focuses on how willing people are to pay additional costs over your present bill for getting renewable energy. Power supply, about $42 \%$ of participants are ready to pay $1 \%$ to $10 \%$ of additional costs for get renewable power, whereas $16 \%$ of participants answered $10 \%$ to $20 \%$ and nearly $5 \%$ are ready to pay more than $20 \%$ of extra costs and about $37 \%$ not ready to pay extra cost, maybe due to economical reason or lack of knowledge. Based on the results, the people care about environment, and they want to protect environment. generally, every one wishes to avail the cheapest choice. The government should work to-wards the potentials to propose such business-models which are equal in cost with to-day's spending on power. If we can over-come the cost fence, the social-acceptance of green energy will rise. The question eight was more emphasis on renewable energy utilization can decrease the power costs in the future. $57 \%$ of responses thought that using renewable energy can decrease power costs in the future, whereas about $36 \%$ of respondents don't know if it can or can't, and approximately $7 \%$ respondents are (no). These responses have positive indication to-wards the use of renewable energy sources. The question nine was formed to know participants opinion about if they actually want to invest in renewables and what the expected pay-back period should be. It was surprising to recognize that about $58 \%$ of participants don't know about payback period, while about $30 \%$ preferred longterm period investment (6-9 years) and $12 \%$ of people responded short term period investment (1-3 years). This means that people have a lack of knowledge about investing in the renewable energy.

Table (4) : Section two: The survey results questions 5-9 (Interviewees willingness to invest in renewable energy source and technologies).

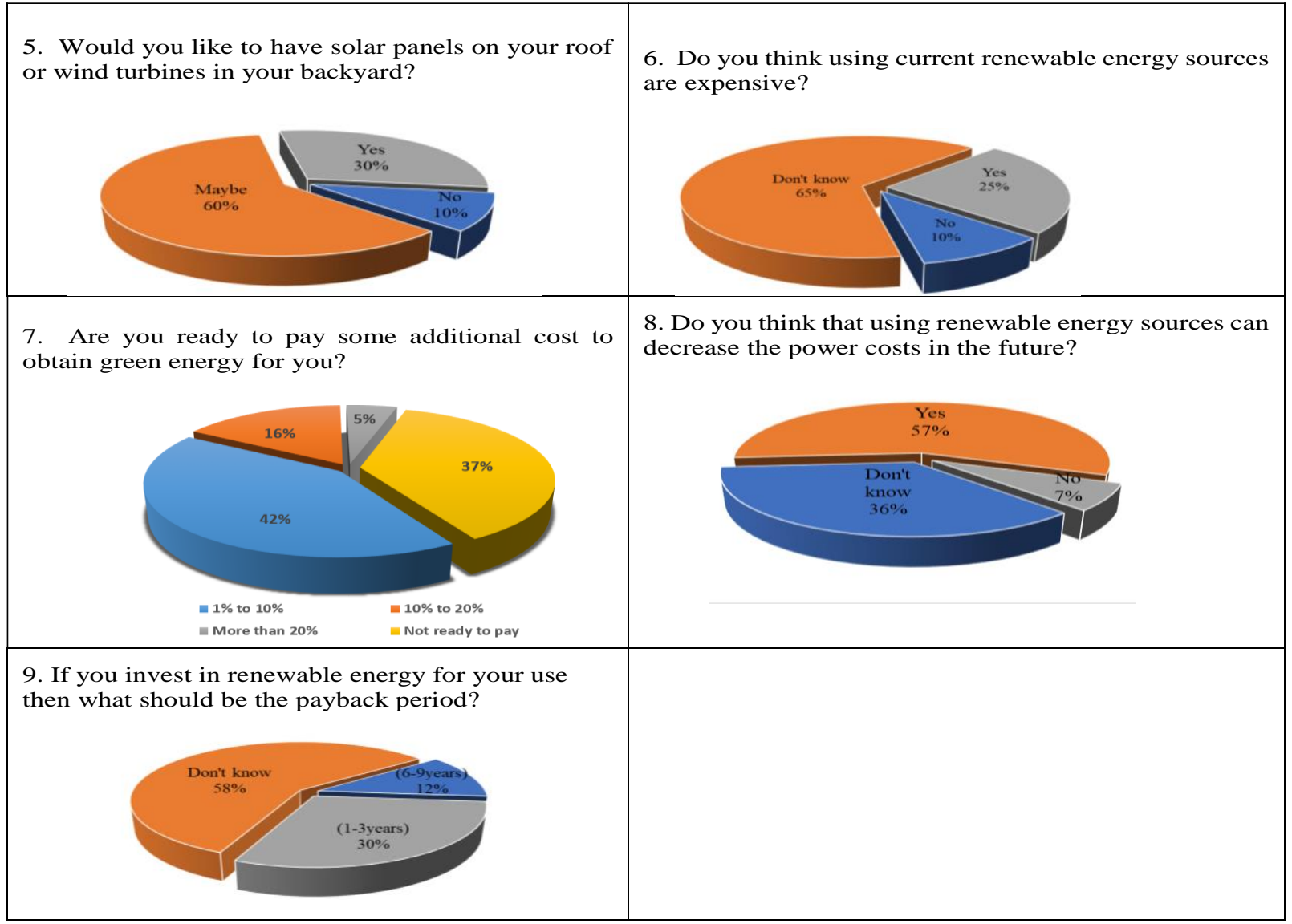




\section{CONCLUSIONS}

Based on the qualitative review of the study, Kurdistan region has great ability to utilize renewable energy resources, that leads to reduction of using fossil fuel for electricity generating, and environmental benefits (reducing CO2 emission) as well as increase security of supply. While, based on the quantitative results, it became clear during the interview that personal cases were different. For example, older age groups of people were less aware of the concept of renewable energy sources, and less worried about development of renewable energy and the environmental problem issues in Kurdistan. In contrast, lower age groups between (18-24 years) were more conscious about concept and development of renewable energy. While for teenagers between 15 and 18 years, they don't know about Kurdistan RES to some extent. It is correlated to the educational level, common sense and the home environment in addition to the social-experience; they will collect more information and commonsense experience as they grow-older, the authorities must take measures to increase vision of teenagers on renewable energy sources and environmental protection. Hence, involvement teenagers in this study, would increase their aware-ness of the potential of renewable energy sources in power saving. Moreover, the results show that levels of social awareness and knowledge of different forms of energy sources and their effects have shaped a rather varied set of results in section because of the diverse nature of questions asked, as well as to respondents various social-demographic characteristics, socio-economic, background information, etc. The results indicate that the in-depth under-standing of renewable energy sources differs markedly. Around $60 \%$ of participants have understood that it is essential to produce, develop and improve the renewable energy sources and technology at present, while around $30 \%$ of the respondents want to take practical steps for development of renewable energy, for instance, fixing solar panels and wind turbines on their roof. Moreover, the results show that about $63 \%$ of participant are ready to pay additional cost over his present bill to obtain renewable energy power supply; about $42 \%$ would like to pay $1 \%$ to $10 \%$ extra cost in this regard. While, they showed a mixed set of acceptance concerning the regional production of the renewables. Perception, political, Knowledge, beliefs and fear are correlated with social-acceptance in this regard. For instance, a majority of participant suggestion that public sector must take the start point to-wards production of renewable energy. In the near future, the Government will play a significant role in motivating and developing the concept of renewable energy in-to real solutions. More specifically, the results show that Kurdish community do expect more from the public sector about production of RES. The connection between the Kurdish society expectations and the government is very significant to take some work to build and establish confidence in RES and its applications in the ground. Therefore, this stage allows to know how to organize levels of confidence, perceptions and knowledge in social-acceptance responses about renewable energy sources issues. Recommendations for developing RES in the region can be summarized as follows:

- Kurdistan used only hydropower as renewable energy source for generating electricity power but still limited. if it utilized in the correct way, it can be a main source for electricity production because there are many river and streams in KRG.

- Kurdistan has great potential of solar energy, it can be utilized solar cells or solar thermal collectors in the public building and residential building to reduce the need for fossil fuels, energy demand and energy bill in the future.

- Kurdistan has potential of wind power generation, it can install large wind turbines in the muntin's or small wind turbines in the public and individual building, this may reduce energy demand.

- Kurdistan is very rich in biomass source, and the using biomass energy source for produce of electricity is can be limited comparison with hydropower and solar energy but may be sufficient if used efficiently.

- The Government should support studies and pilot projects in RES epically, solar and hydropower energy resources, and supported financially by government.

- In order to develop renewable energy, there is a need for future work to highlight the in-depth knowledge of people about the importance of using current renewable energy sources, and we need tack into consideration all variables related to social-acceptability of renewable energy.

\section{REFERENCES}

1. Ahmed, R. I., Mohammed, A. S. (2010). Wind energy potential in garmyan zone. Diyala journal for pure sciences, 6(2), 170-182.

2. Azabany, A. Khan, K. (2014). Energy analysis for replacing fossil fuel energy source of electricity withsolar cells in the uk and kurdistan, iraq. Asian Journal of Science and Technology, 5(9), 541-545.

3. Christian Reuter and Thomas Spielhofer. (2017). Towards social resilience: A quantitative and qualitative survey on citizens' perception of social media in emergencies in Europe. Technological Forecasting and Social Change, 121, 168-180.

4. Devine-Wright, P. (2007). Reconsidering public attitudes and public acceptance of renewable energy technologies: a critical review. Manchester: Manchester Architecture Research Centre, University of Manchester. 
5. Devine-Wright, P. (2011). Enhancing local distinctiveness fosters public acceptance of tidal energy: A UK case study. Energy Policy, 39(1), 83-93.

6. Devine-Wright, P. (2011). Place attachment and public acceptance of renewable energy: a tidal energy case study. J. Environ. Psychol, 31, 336-343.

7. Ekurd. (2016). Privatisation of Iraqi Kurdistan's electricity to solve power shortage: ministry. Retrieved 9 9, 2017, from http://ekurd.net/privatisationkurdistan-electricity-2016-08-11

8. Hamadamin, H. K., Jahfer, M. S., Hemn, M. S. (2015). Utilization of Solar Energy for Electricity Generation in Kurdistan - Koya City. Advances in Energy and Power, 3(2), 15-18.

9. Hamed, M. J., Yousif, A. K., Fakhri, H. I. (2013). Environmental Issues in Erbil City. International Journal of Engineering Trends and Technology (IJETT), $4(8), 3509-3515$.

10. HenrikLund. (2010). Renewable energy strategies for sustainable development. Energy, 32(6), 912-919.

11. Hussein, A. K., Miqdam, T. C. (2012). Status and future prospects of renewable energy in Iraq. Renewable and Sustainable Energy Reviews, 16, 60076012.

12. Issa, B. (2014). Mega-project plans for developing the power and water sector in iraq and kurdistan region of iraq. Dubai: UAE.

13. JanUrban and Milan Ščasný. (2012). Exploring domestic energy-saving: The role of environmental concern and background variables. Energy Policy, 47, 69-80.

14. JeffreySwofford and MichaelSlattery. (2010). Public attitudes of wind energy in Texas: Local communities in close proximity to wind farms and their effect on decision-making. Energy Policy, 38(5), 2508-2519.

15. KRG. (2017). Kurdistan's geography and climate. Retrieved 9 10, 2017, from http:/ / www.gov.krd/p/p.aspx?l=12\&p=213

16. kurdishglobe. (2013). Power production to double in three years. Retrieved 9 12, 2017, from Erbil Governorate:

http:/ / hawlergov.org/en/article.php?id=1360835393 17. Malik, F. A. (2014). Fisheries and Aquaculture Activities in Kurdistan Region. Retrieved 1 9, 2017, from

slideshare: http://www.slideshare.net/firasaljader/fisheries-andaquaculture-activities-in-kurdistan-region

18. Mirza, S. A., Arif,A. A. (2015). Economical Environmental and Performance Analysis for a200 KW Ground Mounted Photovoltaic System: Koya City,Kurdistan of Iraq. International Journal of Engineering Technology, Management and Applied Sciences, 3(3), 72-84.

19. Mohamed, T. A. (2011). Country Pasture/Forage Resource Profiles iraq. iraq: FAO. Retrieved 2017, from http://www.fao.org/ag/agp/AGPC/doc/Counprof/ PDF\%20files/iraq.pdf

20. N.Hall, P.Ashworth, P.Devine-Wright. (2013). Societal acceptance of wind farms: Analysis of four common themes across Australian case studies. Energy Policy, 58, 200-208.

21. Populus. $(2005,6)$. Energy Balance of Power Poll Fieldwork. Retrieved 9 25, 2017, from http://www.populus.co.uk/wpcontent/uploads/2016 /01/download_pdf-060705-The-Times-Energy-balanceof-power.pdf

22. Qusai, Y. A., Lookman, M. M. . (2012). Dust storm in Erbil city as a result of climatic change in Kurdistan Region Iraq. Iraqi Journal of Science, (pp. 40-44). Baghdad,.

23. Scddeek, R.E.,Wahab, S.K. (2013). Wind Energy Proposed In Kurdistan-Iraq. Journal of Engineering Research and Applications, 3(6), 1531-1535.

24. UNDP. (2015). Reconstruction of the Kurdistan Region's Electricity Sector. Retrieved 9 10, 2017, from http://www.iq.undp.org/content/iraq/en/home/ope rations/projects/poverty_reduction/kr-electricityreconstruction.html

25. Viswanath Venkatesh and Hillol Bala. (2008). Technology Acceptance Model 3 and a Research Agenda on Interventions. Decision Sciences, 39(2), 273315.

26. Wolsink, M. (2000). Wind power and the NIMBYmyth: institutional capacity and the limited significance of public support. Renewable Energy, 21(1), 49-64.

27. Yassen, H. (2016). Energy Sources and Utilization in Iraq Kurdistan Region. Ministry of electricity Kurdistan region. Retrieved 12 1, 2017, from https://eneken.ieej.or.jp/data/4502.pdf. 